\title{
Türk Basınında Suriyeli Göçmenlere İlişkin Haberlere Yapılan Yorumların İncelenmesi*
}

\author{
Examining of the Comments related to News on the Syrian Migrants in the \\ Turkish Press
}

\author{
Dr. Öğr. Üyesi Emrullah TÜRK ${ }^{1}$
}

\begin{abstract}
Özet
Tarih boyunca yaşanan kitlesel göçler yöneldiği toplumun ekonomik, siyasal, sosyal ve kültürel yapısını derinden etkilemiştir. Tarihin değişik dönemlerinde birçok kitlesel göçe ev sahipliği yapmış olan Türkiye, 2011'den bu yana Suriye'de iç karışıklıklar sonucu başlayan kitlesel göçlerle karşı karşıya kalmıştır. Göç idaresinin Ağustos 2018 verilerine göre, 2011 Nisan ayından bu yana Türkiye'de geçici koruma altında bulunan Suriyeli göçmen sayısı 3 milyon 500 bin'i aşmıştır. $\mathrm{Bu}$ makalede, Türkiye'de Suriyeli göçmenlere bakış açısının hangi yönde ilerlediği sorgulanmaktadır. Göçmenlere yönelik inşa edilen tutumların somut olarak yansıma biçimlerine dair internet ortamında rastlanan örnekler üzerinden Suriyelilerin, Türkiye'de ötekileştirilip/ötekileştirilmediğine ya da ne düzeyde ötekileştirildiğine dair sonuçlara ulaşılmaya çalışılmaktadır. Bu kapsamda internet temelli haberlere yapılan yorumlar üzerinden elde edilen veriler betimsel olarak analiz edilmiştir. Türkiye'deki ana akım gazete haberlerinde "Suriyeliler" anahtar kelimesiyle irdelenen haberlere okuyucuların yapmış olduğu yorumlardan anlaşıldığı üzere, göçmenlere tanınan ekonomik, sosyal hakların yanında münferit bazı olaylar yerli halkın Suriyeli göçmenlere bakış açısını derinden etkilemekte, göçmenlerin toplumsal konumunun "ötekilik" tecrübesi üzerinden şekillendiği ve bu anlayışın "misafirlik" söylemini etkisizleştirdiği sonucuna ulaşılmaktadır. Ancak bunun yanı sıra bu tür bir bakış açısının, başlangıçtan bu yana "açık kapı" politikasıyla Suriyelilere kucak açan hükümetlerin ve yerel halkın genel duruşunu da yansıtmaktan uzak olduğu sonucuna varılmaktadır.
\end{abstract}

Anahtar Kelimeler: Göç, Suriyeli göçmenler, haber medyası, ötekileştirme, Türkiye

Makale Türü: Araştırma makalesi

\begin{abstract}
Mass migration has profoundly influenced the social, economic, political and cultural structure of the migration-receiving societies throughout history. Turkey that hosted several mass migrations in different periods has faced a mass migration from Syria since 2011 as a result of civil war. According to the Ministry of Internal Affairs Directorate General of Migration data by 2018 August, the number of Syrian migrants under temporary protection since April 2011 is over 3.500.000. In this article, it is dealt with the change of views about Syrian migrants in Turkey. It is tried to come to a conclusion about the level of othering of Syrians in Turkey looking at examples on the internet regarding the reflection of attitudes concerning migrants and if there is an othering discourse about Syrians in public. Therefore, the news on the internet is analyzed and some data is obtained from this news. The
\end{abstract}

\footnotetext{
* Bu makale, 14-15 Kasım 2017'de Sakarya Üniversitesi’nde gerçekleştirilen II. Türk- Cezayir Sosyal Bilimler Konferansı'nda yer alan sözel bildiri sunumunun geliştirilmesiyle oluşturulmuştur.

${ }^{1}$ Batman Üniversitesi, Fen-Edebiyat Fakültesi, dremrullahturk@gmail.com, Orcid ID: https://orcid.org/0000-0002-2464-2556
} 
data is analyzed descriptively. The news and reader comments regarding Syrian migrants titled as "Syrians" in mainstream newspapers in Turkey is analyzed and it is found that Turkish people's view of Syrians is deeply affected by some local problematic events in the eyes of host people, social position of migrants is shaped by "otherness's experience, and this situation has neutralized the discourse of 'guest' status of these Syrian migrants. However, in addition to all these factors such a point of view is far from reflecting the government's and local people's general stance who embrace Syrians with 'open door' policy from the beginning onwards.

Key Words: Migration, Syrian migrants, news media, othering, Turkey

Paper Type: Research paper

Giriş

2010 yılı sonlarında birçok Arap ülkesinde başlayan ve çoğu kişi tarafından "Arap Baharı" olarak nitelendirilen protesto hareketleri, 2011 yılının başından itibaren Suriye'ye de sıçramıştır. Gelinen noktada sonuçları itibariyle çok geniş bir coğrafyayı etkisi altına alan bir süreç yaşanmaktadır. Türkiye, bu sürecin sonuçlarının dolaylı etkisi altına giren ülkelerin başında gelmektedir. Yaşanan iç savaş nedeniyle ülkelerini terk eden Suriyelilerin sığınmak ${ }^{2}$ üzere yöneldiği Türkiye, bu süreçten başta ekonomik ve sosyal olmak üzere birçok açıdan en çok etkilenen ülkelerdendir. Bu süreçte başta insani hassasiyetler, etnik ve dini kimliğin etkisi ile tarihi duygudaşlık, Suriyeli göçmenlerin Türkiye'ye kabulünde belirleyici rol oynamaktadır.

2011 Nisan ayından bu yana Türkiye'ye sığınmak zorunda kalan Suriyeli göçmenler üzerinden gazetelerin internet sitelerindeki haberlerine yapılan yorumları eleştirel bir perspektifle değerlendiren bu araştırma, gazete haberine yapılan yorumları temele almaktadır. Bu haberlere yapılan yorumlar bağlamında Suriyeli göçmenlere dair "öteki"

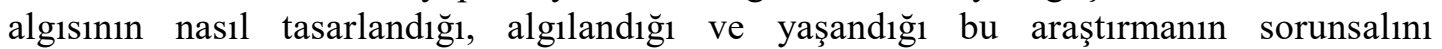
oluşturmaktadır. Buna bağlı olarak da bu makalenin amacı, Türkiye'ye yerleşen Suriyeli göçmenlere bakış açısının ne yöne doğru evrildiğini sorgulamaktır. Bu amaçla, nitel araştırma kapsamında 2017 yılında $^{3}$ (Ocak-Ekim) Suriyeli göçmenleri konu alan ulusal haberler değerlendirilmektedir. Türkiye'deki ana akım medya bu araştırmanın evrenini oluştururken, ana akım medya unsurlarından ve internette en çok ziyaret edilen gazetelerin (Hürriyet, Sabah, HaberTürk) internet siteleri ise örneklemini oluşturmaktadır. Ana akım medyayı temsilen Hürriyet, Sabah, HaberTürk gazeteleri gerek tiraj gerekse internette en çok ziyaret edilen gazeteler olmalarından dolayı seçilmişlerdir. Suriyeli göçmenleri konu alan haberleri kapsayan bu araştırmada basılı haberler kapsam dişı tutulmuştur.

2 Çalışma boyunca, Türkiye'nin 1951 yılında Cenevre Sözleşmesini “coğrafi çekince/kısıt” ile kabul ettiğinden, daha açık bir ifadeyle "Avrupa ülkelerinin birinden kaçan insanları mülteci olarak kabul edip, doğudan ya da Afrika'nın herhangi bir ülkesinden gelip slğınma talep edenlere bu hakk tanımama" politikasından dolayı Suriyeliler "geçici koruma" statüsündeki bireyler olarak kabul edilmektedir. Bu gerekçeden dolayı makalede Suriyeliler, sığınmacı/mülteci tanımları yerine daha genel bir ifade olan göçmen tanımı tercih edilmektedir.

\footnotetext{
${ }^{3}$ Savaşın başından bu yana her iki halkın karşı karşıya gelme sıklığının 2017 yılında daha da arttığına dair tespitlerden dolayı çalışma bu yıl içindeki haberlere ilişkin yorumlarla sınırlandırılmıştır.
} 
Çalışma, 2017 yılının ilk 10 ayında (Ocak-Ekim) akım medyayı temsilen Hürriyet, Sabah, HaberTürk gazetelerinin internet arşivlerinde yer alan 'Suriyeliler' haberleri ve bunlara yapılan yüzlerce yorumu kapsamaktadır. 'Suriyeliler' başlıklı haberlere yapılan yüzlerce yorumdan benzer olanları elenerek, birbirinden farklı olan yorumlardan ortak temalar oluşturulmuştur. Bu temalar, kimlik boyutu, güvenlik ve toplumsal düzen, kentsel alanda birlikte yaşa(ma)ma ve ekonomik kaygılar üzerinden şekillenen olumsuz yorumlar ile uyum/kardeşlik üzerinden yapılan olumlu yorumların kategorize edilmesiyle oluşturulmuştur.

Böylesi çok farklı olgu ve olaylardan oluşan nitel verilerin analizinde "Okuyucu yorumlarında yer alan kelimelere, ifadelere, kullanılan dile ve benzetmelere dayanarak tanımlayıcı bir analiz yapılabileceğinden" (Kümbetoğlu,2012:154) betimsel analizin uygun olduğuna karar verilmiştir. Betimsel analizin amac1, "ham haldeki verilerin okuyucuların anlayabileceği ve isterlerse kullanabileceği bir şekle sokulmasıdır." Elde edilen veriler önce mantıklı bir siraya konulur ardından bu betimlemeler yorumlanır ve sonuçlara ulaşılır (Altunışık vd., 2012:324).

Öte yandan bu çalışmanın temel iddiası, günlük hayatta farklı yer ve zamanlarda kitle iletişim araçları üzerinden yayılan haberlere yapılan yorumlarla oluşturulmak istenen nefret söyleminin, genellenemeyeceği ve haber içeriklerinin nefret söylemini besleme riski taşıdığıdır. Münferit olaylar üzerinden tüm göçmenlerin problemli olduğu, bütün suçların kaynağı olduğu ve yerli halkın da neredeyse tamamının bu kişilere karşı bir nefret söylemini benimsediği gibi bir algı yaratma çabası, Türkiye toplumunun başlangıçtan bu yana gösterdiği insani hassasiyetleri görmezden gelmek olacaktır.

\section{Biz ve Öteki İkileminde Türkiye’deki Suriyeli Göçmenler}

Kimlik, toplumsal sistemi oluşturan bireylerin algılarının ve düşün biçimlerinin şekillenmesine aracılık eden davranış kalıplarının bütününü ifade eden bir kavramdır. Kimlik, aynı zamanda sosyal, kültürel, ekonomik ve siyasi çevre ile etkileşimden doğan inanç, tutum ve değer yargılarıyla karakterize edilen yaşam felsefesini ifade eder (Yıldız,2007:9). Ayrıca, kişiyi bir başkasından ayıran, doğuştan getirilen özelliklerin yanında yaşam boyu elde edilenlerle şekillenen bir aidiyetler bütünü (Maalouf, 2011: 16 akt. Türk, 2016:1158) olarak da tanımlanmaktadır. Yani bireyin, fiziki özelliklerinin yanında zamanla girdiği bir meslek grubu, parti, sendika, cemaat gibi aidiyetler de kimliğinin bir parçasını oluşturmaktadır. Bireylerin kişilik özelliklerinin yanında içinde bulundukları toplumla kurdukları karşılıklı etkileşimden ortaya çıkan kimlikler, bireyin o toplumla kuracağı ilişkilere genel şeklini veren aidiyet duygularını içerir. Bireyin grup aidiyetinin sınırlarını çizen kimlik, Parsons'ın (1964:26-28) deyimi ile içinde bulunulan gruba ait ortak deneyimler üzerine kuruludur. $\mathrm{Bu}$ şekilde ortak anlamlar üzerine kurulan kimlik, toplumda kollektif kimliklerin temelini oluşturur (Özbek,2006:13-14). Kollektif aidiyetler çerçevesinde inşa edilen ortak kimlikler ise, benzerlikler ve ortaklıklar paydası üzerinde kuruldukları için diğerlerine benzememe, onlardan farklı olma anlayışını da doğal olarak taşımaktadır. Buna dayalı ortaya çıkan "farklılık" algısı toplumsal sistemler içinde "biz" ve "'öteki ayrımının doğmasına neden olur (Guibernau, 1997:127). Bu bağlamda toplumsal bir kategori olarak ortaya çıkan "'biz" ve "öteki" ayrımı, birbirini var eden, tamamlayan bir süreçtir (Onur,2003:260). Her yeni insan grubu tanımlanırken kendi kültürel ölçütlerine göre ortaya 
çıkan "öteki” grup söz konusu olmakta ve bu "öteki” grup anlayışı genelde "aşağıda" olma haline dönüşmektedir (Schnapper,2005: 25-30).

Toplumsal sistem içinde farklılık temelli inşa edilen kimlikler, tarihsel süreç içinde toplumsal, siyasal, teknolojik, doğal ya da ekonomik değişimler gibi nedenlerden dolayı karşı karşıya gelebilmektedir. Bu bağlamda kimliksel düzlemde toplumları karşı karşıya getiren önemli unsurlardan bir tanesi de göç olgusudur.

Sosyolojik anlamda göç, bir takım gerekçelerle bir yerden başka bir yere taşınma anlamına gelmekte; irade, sınır, süre ve yerleşim yerine göre birçok açıdan sınıflandırıldığ görülmektedir (Türk,2016:54). Göç, insanlık tarihi kadar eski, toplumsal yapıyı derinden etkileyen, sebepleri ve sonuçları itibariyle karmaşık bir sürecin adıdır. Bazen tek bir sebep bazen de birden çok sebebe dayalı olarak gerçekleşebilir. Başta ekonomik olmak üzere birçok sebepten kaynaklanabilen, birey ve topluluk düzeyinde gerçekleşen bu hareketlilik, gerçekleştirenleri olduğu kadar bu hareketliliğin nihai noktasında yerleşik halde bulunan toplumları da derinden etkileyen ve karş1lıklı etkileşimler doğuran bir süreçtir. Bu sebeple göç hareketliliği bir madalyona benzetilebilir. Madalyonun bir yüzünü göçmenler oluştururken diğer yüzünü ise ev sahibi konumunda bulunanlar oluşturmaktadır. Ev sahibi konumunda bulunan toplumun göçmenlerle kurduğu ilişki biçimi, yeni yerleşim yerindeki uyum sürecinde de belirleyici bir rol oynamaktadır.

Göç, irade bakımından tanımlandığında serbest irade/gönüllü veya güdümlü/zorla/zorunlu şeklinde iki tipte kavramsallaştırılmaktadır (Akkayan, 1979: 22-23; Fichter,2012:181). Tarihin her döneminde farklı niteliklerde gerçekleşen göçlerde ekonomik faktörün yanı sıra belirleyici olan bir diğer faktör de insanların yaşadıkları yerlerdeki çatışmaların yarattığı güvensiz ortamdır. İç karışıklıklar veya savaş halinin yarattığı güvensiz ortam, insanların bulundukları yerleri bireysel ya da kitlesel olarak terk etmelerinin temel belirleyicilerdendir. Bu bağlamda 2011 yılından bu yana Suriye topraklarından Türkiye'ye yönelen nüfus hareketi "güdümlü/zorla/zorunlu göç" adları altında değerlendirilebilir.

Göçü tanımlarken çeşitli düzey ve dozlarda çatışan ve gerilimleri dikkate alan, güvensizlik algısıyla dinamik biçimde evrilen bir süreç olarak gören kuramsal bir çerçeveye ihtiyaç vardır. Göç bir defa olan ve bireylerin karşılaştıkları durumları, gereksinim ve isteklerine dayanan tek başına karar verdikleri akılcı bir olgu değildir (Sirkeci ve Cohen,2015:138). Dünya üzerinde süregelen çatışmalar ve bunların yarattığı güvensiz ortam bu sürecin asıl tetikleyicisi konumundadır. Göç, insanların içerisinde yaşadığı coğrafyada çoğu zaman yaşama olanaklarının hızla tükendiği bir anda gerçekleşir. Başlangıçta, karar verici olarak bireyin kendisi gibi görünebilir ve bu bir tercih olarak değerlendirilebilir. Fakat karar vermek zorunda kalmak, bireylerin kendi inisiyatifleri dişında gerçekleşen durumlardan kaynaklanmaktadır. Yaşadıkları ülkedeki belirsizlik, güvensizlik hali ya da çatışmaların yarattı̆̆ tehditler sonucu bulundukları yerleri terk etmek zorunda kalan mülteci/sı̆̆ınmacı diye tanımlanan bireyler çok zorlu süreçlerden geçmektedirler.

Göç, tarihin her döneminde gerçekleşmekle birlikte özellikle moderniteyle birlikte hız kazanan ve sanayileşmenin dinamik etkisiyle Dünya'nın farklı coğrafyalarını belirli oranlarda etkileyen nüfus hareketliliğidir. Bu bağlamda Türkiye'nin göçü deneyimleme biçimine bakılacak olursa, bu sürecin ulus-devlet anlayışının hâkim kılınması ile yakından alakalıdır. Bir yandan 1. Dünya savaşı ve sonrasında ülke içinde bulunan gayrimüslimlerin 
ülke dışına göçü ve Balkanlardan Türkiye'ye yönelen göçler; bir yandan da çağdaşlaşma ilkesi gereği kentleşmenin özendirilmesiyle başlayan kırdan kente içgöçlerdir.

Anadolu toprakları, geçmişte olduğu gibi bugünlerde de farklı coğrafyalardan değişik sebeplerden dolayı büyük kitlelerin sığındığı güvenli bir liman konumundadır. Gerek düzenli/yasal gerekse düzensiz/yasal olmayan şekilde gerçekleşen kitlesel göçler, Osmanlı'nın son dönemlerinde olduğu gibi yeni kurulan Türkiye Cumhuriyeti'nin de bir nevi alın yazgısıdır. Balkanlardan, Kafkaslardan, Ortadoğu'dan ve Asya'nın değişik bölgelerinden sık sık bireysel ve kitlesel göçlerle karşı karşıya kalan Türkiye, zorlu şartlara rağmen göçmenlere karşı kucaklayıcı olmayı sürdürmüştür. Cumhuriyetin ilk yıllarında çoğunlukla etnik ve dini yakınlıktan kaynaklı kitlesel göçler, sonraki yıllarda Doğu bloku ülkelerinde yaşanan sıkıntılardan kaçan farklı etnik ve dini grupların ya da kişilerin göçleriyle devam etmiştir. Yakın dönemlerden bu yana ise çoğunluğu Irak ve Suriye gibi komşu ülkelerden Türkiye'ye yönelen göçler söz konusudur. Bu göçlerin en sonuncusu ise iç karışıklıklar sonucu Suriye'den Türkiye'ye yönelen nüfus hareketliliğidir.

Küreselleşmenin etkisi de dikkate alındığında Türkiye, yakın dönemlerden itibaren Ortadoğu coğrafyasında yaşanan ekonomik ve siyasal dönüşümlerin etkisiyle hem "transit" hem de "göç alan" ve "göç veren" ülke konumlarını bir arada sürdürmektedir. Türkiye, ulus ötesi göçlere ilişkin değişen konumuyla beraber, her geçen gün daha fazla kalıcı göçmen nüfusa ev sahipliği yapan bir ülkeye dönüşmektedir. Birleşmiş Milletler Mülteciler Yüksek Komiserliği (UNHCR) tarafından hazırlanan Küresel Eğilimler Raporu (2017) ve Göç Vakfi (2018) araştırma verilerine bakıldığında Türkiye'nin ne denli büyük bir yük altına girdiği açıkça görülebilir. 29 Nisan 2011 tarihinden bu yana ülkelerindeki çatışmalar, zulüm ve güvensiz ortam nedeniyle Türkiye'ye göç etmek zorunda kalan/yerinden edilen Suriyeli göçmenler, 7 yıllık süreçte büyük çoğunluğu sınıra yakın illerde olmak üzere ülkenin tamamına dağılmış ve sayıları 3 milyon 500 bini aşmıştır. Bugün Türkiye "açık kapı" politikası ile topraklarında en çok Suriyeli göçmen barındıran ülke konumundadır.

Ekonomik, sosyal, hukuki ve siyasi yönleriyle çok boyutlu olan bu durumun, aynı zamanda da çok boyutlu olarak değerlendirilmesi gerekmektedir. Sebep ve sonuçları itibariyle çok boyutlu olan bu hareketliliğe ilişkin faaliyet yürüten teşkilatlar bulunmaktadır. Bunlardan biri İçişleri Bakanlığına bağlı Göç İdaresi Genel Müdürlüğü ${ }^{4}$ dür.

Başta Göç İdaresi Genel Müdürlügü olmak üzere diğer kuruluşlar ve ev sahibi konumundakilerin insani katkıları -başlangıç aşamasındaki göçmen sayısı da dikkate alındığında- ilk zamanlar Türkiye'nin baş edebildiği bir durumdayken, süreç uzadıkça Suriyeli göçmenlerle alakalı sorunlar artmaya başlamıştır. Ayrıca sürecin uzaması, göçmenlerle ev sahibi konumunda olanların farklı gerekçelerle karşı karşıya gelme ihtimallerini artırmaktadır. Bu karşı karşıya gelişler, ev sahibi konumundakilerde, başta ekonomik olmak üzere sosyo-kültürel ve güvenlik gibi konularda belirli hassasiyetlerin gelişmesine neden olmaktadır. Münferit bazı olaylar ev sahibi konumundakilerin, Suriyeli

\footnotetext{
4 Göç İdaresi Genel Müdürlüğü, göç alanına ilişkin politika ve stratejileri uygulamak, bu konularla ilgili kurum ve kuruluşlar arasında koordinasyonu sağlamak, yabancıların Türkiye'ye girişi ve Türkiye'de kalışları, Türkiye'den çıkışları ve sınır dışı edilmeleri, uluslararası koruma, geçici koruma ve insan ticareti mağdurlarının korunmasıyla ilgili iş ve işlemleri yürütmekle sorumludur (GİGM,2017:17).
} 
göçmenlere bakış açısını derinden etkilemekte ve göçmenlerin toplumsal konumu "ötekilik" tecrübesi üzerinden şekillenmektedir. Bu süreç aynı zamanda "misafirlik" söylemini de etkisizleştirmektedir. Suriyeli göçmenlerin kısa süreli olarak "misafir" edileceği düşüncesi, bu savaşın Dünya'nın en vahşi vekâlet savaşlarından birine dönüşmesiyle birlikte içinden çıkılmaz bir hâl almakta ve süreç Türkiye açısından Suriyelilerin geçicilikten kalıcılığa doğru evrildiği bir noktaya doğru kaymaktadır.

\section{Suriyeli Göçmenlerle İlgili Habere Yapılan Okuyucu Yorumlarının İncelenmesi}

Türkiye'ye yönelen Suriyelilere ilişkin çalışmalara bakıldığında bu konuda literatürün zenginleşmeye başladığı görülmektedir. Ancak diğer çalışmalar ${ }^{5}$ dan farklı olarak bu çalışma, ana akımı temsilen üç gazetenin internet sitelerinde yer alan haberlerden "Suriyeliler" kelimesi kullanılarak elde edilen haberlere okuyucular tarafindan yapılan yorumlar ${ }^{6}$, çalışmanın odak noktasını oluşturmaktadır. Burada gazetelerin bakış açılarından ziyade okuyucuların yaptıkları yorumlara dikkat çekilmektedir. Böylelikle, sadece olayın içinden olanların değil, daha geniş çerçevede bu olayların nasıl değerlendirildiği anlaşılmaya çalışılmaktadır. Bu yorumlardan hareketle toplumda göçmenlere karşı açığa çıkan kalıp yargılara (stereotip) dikkat çekilmektedir.

Bu çalışma kapsamında analize tâbi tutulan her üç gazetede de 2017 yılında ön plana çıkan haber başlıkları aşağıda belirtilmektedir:

- Ankara'da Suriyelilerle vatandaşlar arasında gerginlik (HaberTürk,04/07/2017 tarihli haberi)

- Küçükçekmece'de tehlikeli gerginlik (Hürriyet, 14/07/2017 tarihli haberi)

- Mahallede Suriyelilerle gerginlik (İstanbul/Fatih) (Sabah, 17/10/2017 tarihli haberi)

- 'Gürültü yapmayın' deyince öldürüldü, sokak karıştı (Mersin) (Hürriyet,15/05/2017 tarihli haberi)

- Illçeyi karıştıran kavga (Denizli/Sarayköy) (Hürriyet, 19/03/2017 tarihli haberi)

- Şanlıurfa'da tehlikeli 'Suriyeli' gerginliği! (Sabah, 27/03/2017 tarihli haberi)

\footnotetext{
${ }^{5}$ Murat Erdoğan'ın (2014) “Türkiye'de Suriyeliler: Toplumsal Kabul ve Uyum” adlı eseri, gerek toplumsal kabul gerekse ulusal ve yerel gazetelerin internet sitelerinde Suriyeli göçmenlere ilişkin haberlerin analizi açısından önemlidir. Bunun yanı sıra Çağlar ve Özkır'ın (2015) bazı köşe yazarlarının göçmenlere ilişkin yorumları üzerinden yapmış oldukları çalışma ile Göker ve Keskin'in (2015) beş ulusal gazetedeki Suriyeli göçmen temsiline ilişkin çalışmaları medyanın tutumunu göstermesi açısından önemli çalışmalar olarak değerlendirilebilir.

6 Çalışma boyunca her yorumun ardından kaynakların tekrar tekrar belirtilmesi yerine ana kaynaklar birer defa kaynakçada belirtilmektedir.
} 
- Konya'da tehlikeli gerginlik: Satır, taş ve sopalarla... (Sabah 04/10/2017 tarihli haberi)

- Suriyelilerin gönderilmesini isteyen mahalleli eylem yaptı (Adana) (HaberTürk, 22/05/2017 tarihli haberi)

- Mersin'de Suriyelilerle belde halkn arasında gerilim (HaberTürk, 17/04/2017 tarihli haberi)

- İçişleri Bakanlığı'ndan son günlerde "Suriyelilerle yaşanan gerginlikler"e ilişskin açıklama (Sabah, 05/07/2017 tarihli haberi)

- Başbakan Yardımcısı: Hoşgörüyü elden bırakmayalım... (Hürriyet,05/07/2017 tarihli haberi)

Genel olarak, toplumsal huzursuzluklar ana başlı̆ğ altında toplayabileceğimiz bu haberlerin içeriğinde, büyükşehirlerde Suriyeli göçmenlerle vatandaşlar arasında çıkan kavgalar ön plana çıkmaktadır. Bu haber başlıkları başlı başına olumsuz çağrışımlar içermektedir. Örneğin bir haberde; Ankara'da Suriyeli mültecilerle vatandaşlar arasında çıkan kavgada, gergin anların yaşandı ğı, meydana gelen olaylarda 1 kişi yaralanırken, polis ekiplerinin vatandaşlara biber gazlyla müdahalede bulunduğu bilgisine yer verilmektedir. Ayrıca çıkan kavga haberinin sosyal medyada paylaşımıyla birlikte olay yerine çok hızlı bir şekilde vatandaşların toplandiğı bilgisi de paylaşılmaktadır (Hürriyet, 04.07.2017 tarihli internet haberi). Bir başka haberde ise; Şanlıurfa'da kısa sürede büyüyen Suriyeli ile Türk çocukların kavgası, yaklaşık 100 kişilik grup arasında taşlı, sopalı ve bıçaklı kavgaya dönüştüğ̈̈ bilgisine yer verilmektedir (Haber Türk, 31.05.2017 tarihli internet haberi). Yaşanan bu olayların taşlı, sopalı, bıçaklı kavgalara dönüştüğü, linç girişimlerin olduğu ve bu kavgalar sonucunda birçok yaralının yanı sıra ölenlerinde olduğu bilgisi değişik haber sitelerinde paylaşılan haberlere ilişkin ortak sonuçlardır. Bu haberlerden de anlaşılacağ üzere haber sitelerinin Suriyeli göçmenlere ilişkin haber başlıkları ve içerikleri genel olarak olumsuz çağrışımlar içermekte ve olumsuz çağrışımlar okuyucu yorumlarına da yansımaktadır.

Çalışmada, haber başlıkları altında okuyucuların haberlere yaptıkları yorumlar olumlu ve olumsuz olarak sınıflandırılarak çeşitli temalar altında ele alınmaktadır. $\mathrm{Bu}$ bağlamda Suriyeli göçmenlere ilişkin yorumların büyük bir kısmı olumsuz olmakla birlikte, bu haberlere yapılan yorumlar beş tema altında değerlendirilmektedir. Bunlar;

- Kimlik Boyutu Üzerinden Yapılan Yorumlar

- Güvenlikve Toplumsal Düzen Üzerinden Yapılan Yorumlar

- Kentsel Alandan Birlikte Yaşa(ma)ma Üzerinden Yapılan Yorumlar

- Ekonomik Kaygılar Üzerinden Yapılan Yorumlar

- Uyum/Kardeşlik Üzerinden Yapılan Yorumlar 


\subsection{Kimlik Boyutu Üzerinden Yapılan Yorumlar}

Suriyeli göçmenlerin Türk yazılı basınındaki temsiline ilişkin yapılan bir çalışmada (Göker ve Keskin, 2015:247) görüldüğü üzere "Ana akım haber gazetelerinde yer alan haber başlıklarının ortak noktasını kategorize etme ve yaftalama oluşturmaktadır. Haberlerde temsil edilen aktörler, yasal statüleri olan "mülteci" ya da "sı̆̆ınmacı" yerine genel olarak "Suriyeli" olarak tanımlanmıştır. Toplumsal bağlamda olumsuz ve küçümseyici bir anlam karşıllğı bulan bu söylem ile aktörlerin asıl kimlikleri göz ardı edilerek etnik ve edilgen kimlikleri ön plana çıkarılmıştır". Çalışmamızda da gerek haber başlıkları gerekse haberlere yapılan yorumlarda "Suriyeli" stereotipi üzerinden şekillenen, büyük oranda olumsuz ve küçümseyici bir dil ön plana çıkmaktadır. Bu yorumlardan bazıları aşağıdaki gibidir;

"Suriyeli istemiyoruz bu kadar net".

"Haber doğru ya da yanlış. Gerçek olan Suriyeliler istenmiyor arkadaş".

"Suriyeliler defolup gidin vatanımdan! Kendi ülkenize hayrınız yok bana mı olacak. Hain yeterince var zaten! İthal hainlere ihtiyaç yok",

"Suriyeliler Türkiye'nin her yerinde sorunlara yol açıyor. Hafta sonu İstanbul Büyükçekmece'yi de karıştırmışlar. Madem ülkeleri bayram tatili geçirecek kadar güvenli, Suriye'ye geri dönsünle"r.

"Suriyeliler ile ilgili yorum yazmaktan bıktım. Suriyeliler bize zorla kabullendirilmeye çalışılan bir millet neresinden bakarsan bak zarar. Vatandaşın büyük çoğunluğu istemiyor".

"Hala bunlar savunanlar var yazlklar olsun. Alin evinize bir Suriyeli aile, lafla Ensar olunmaz. Ben vergilerimin Suriyelilere gitmesini istemiyorum".

"Bu mazluma el açmak falan değil arkadaş. Ne kadar $i$. $k \ldots$ var ülkeye doldurdular. Otobüsler metrolar Suriyeli dilenciler doldu".

$\mathrm{Bu}$ yorumların yanı sıra Suriyelilere karşı duyulan rahatsızlıklarını ironik bir dille ifade eden okuyucular ise;

"Bence 3 milyon Suriyeli yetmez biraz daha gelsin".

"5milyon Suriyeli kesmez bir 5 milyon daha gelsin"... şeklinde yorumlar yapmışlardır.

Yapılan yorumlara bakıldığında, ilk zamanlardaki misafirperverlik söyleminin küçümseyici bir söyleme doğru dönüştüğü söylenebilir. Durkheim'ın ayrımcılık ve şiddet görüngülerini anlamak üzere formüle ettiği "günah keçisi" kuramı (Schnapper, 2005:136) Suriyeli göçmenlerin bugün karşı karşıya oldukları durumu ifade etme noktasında önemlidir. Geçicilikten kalıcılığa doğru evrilen süreç, göç edenler ile ev sahibi konumundaki halkın alg1, beklenti ve kaygı düzeylerinde ciddi değişimlere neden olabilmektedir. Süreç uzadıkça Suriyeli göçmenler, ülkede yaşanan her türlü sıkıntının temel belirleyeni gibi nitelendirilmeye başlanmaktadır. Göçmenler, yaşanan her türlü sıkıntıda bir nevi "günah keçisi" olarak görülmeye başlanmaktadır.

\subsection{Güvenlik ve Toplumsal Düzen Üzerinden Yapılan Yorumlar}

Türkiye'de Suriyeli göçmenler, birçok alanda olduğu gibi güvenlik alanında da çeşitli etkiler yaratmaya başlamaktadır. Güvenlik ihtiyaçlarını karşılayamamadan kaynaklı göç, göçün yöneldiği topraklarda da muhtemel yeni güvenlik sorunları doğurabilmektedir. 
Türkiye, jeopolitik ve stratejik konumu itibariyle gerek iç gerekse dış tehditlerle karşı karşıya kalan bir ülke konumundadır. Belli bir oranda toplumsal kabule rağmen Erdoğan'ın (2014) yapmış olduğu çalışmada Suriyelilerin güvenlik riski oluşturduklarını düşünen \%62,3'lük bir çoğunluğun olduğu dikkatlerden kaçmamalidır. Bu perspektifle değerlendirildiğinde aşağıdaki okuyucu yorumları daha da anlaşılır olacaktır;

"Suriyeliler geldiğinden beridir cinayetler, soygunlar v.b. arttı. Bu gidişle kendi evlerimizden bizi kovacaklar. Sürekli yardım istiyorlar".

"Milletçe diken üstüne getirildik. En ufak bir klvılcım ülkenin zaten iyi olmayan ortamını ateşleyebilir".

"Palazlanmaya başladılar 1-2 yll sonra ne sokakta ne de arabada gidebileceğiz".

"Her gün her yerde bu gerginlik, haberlere hükümet çare bulmazsa halk kendi çare arar" acaba"

"Gençler arasında çıkan ufak bir tartışmaya ne zamandan beri TOMA geliyor

"Elhamdülillah sonunda Suriye'deki savaşı İstanbul Fatih'e kadar taşıdık".

"Avrupa ülkelerinin mülteci istememesinin sebebi bu. Son günlerde taciz olaylarl ülkemizdeki sapıkları geçti. Sonra hoşgörülü olalım. Tabi ya beni taciz etsin ne olcak misafir onlar bişi olmaz diyelim".

"Önemli değil biz hoşgörünün dibine vurduk zaten. Evden çıkmıyoruz. Sokaklar, sahiller ve piknik yerlerini komple onlara bıraktık. Yeter ki mutlu olsunlar, biz çekeriz Suriye'nin cefasinı".

"Bi kere de Suriyelileri uyarın Devlet olarak. Kendi halkının suç oranı daha yüksekmiş. Bizim nüfus 80 milyon. Adamların 3 milyon. Kıyaslamaya gel...Kışkırtma falan yok"..

Erdoğan (2014:25) Türkiye'de Suriyeliler konusu günlük hayatın ve siyasetin bir parçası haline geldiği, son bir yılda Suriyeliler konusunda kaygı yaratacak toplumsal olaylar ve protestoların yaşandığını ve süreç iyi yönetilemezse, hızla yabancı düşmanlığının yayılması, nefret üretme ve saldırılara yönelebilme ihtimalinin yükseldiğini ifade etmektedir. Bu açıdan Türkiye'nin tamamen insani hassasiyetler üzerinden geçici olarak şekillendirdiği politikalarının kalıcılığa doğru evrilmesi gerekmektedir. Suriyeli göçmenlerin kentlerde belli çöküntü bölgelerinde toplanmasıyla, önümüzdeki yıllarda çeşitli güvenlik risklerinin doğabileceği gerçeği akılda tutulmalı ve bu konuda gerekli önlemler biran önce alınmalıdır.

\subsection{Kentsel Alanda Birlikte Yaşa(ma)ma Üzerinden Yapılan Yorumlar}

Suriye'de savaş başladığ günden bu yana gelen ilk kafilelerle birlikte 10 kentte kurulan geçici barınma merkezlerinde yaklaşık 250 bin Suriyeli göçmen barınmaktadır. Savaşın acımasız yüzü ve Türkiye'nin böylesi bir kitlesel akını ön görememesi sonucu, barınma merkezleri dışındaki yaklaşık 3 milyon 250 bin Suriyeli göçmen ise kentlere yönelmiştir. Dolayısıyla göçmenlerden kaynaklı yükün önemli bir kısmını kentler üstlenmektedir.

Göçe maruz kalanlar ile yerleşik konumdakilerin ilk karşılaşmaları "misafir" algıı1 üzerinden yürümekteyken aradan geçen 7 yılda bu algı önemli bir değişime uğramıştır. Ev sahibi konumunda olanların toplumsal kabulü, zaman zaman gelişen olaylarla nefret söylemi ile sekteye uğramaya başlamıştır. 
Gazetelerin haberlerine yapılan yorumlar bunu daha net göstermektedir. Yorumların bir kısmında açık bir şekilde okuyucular, göçmenlerle birlikte yaşamak istemediklerini ve göçmenlerin kamplara yönlendirilmeleri gerektiğini savunmaktadır:

"Suriyelilerle beraber yaşamak istemiyorum".

"Suriyeliler yüzünden şehirlerimiz yaşanmaz oldu. Yeter acil çözüm”.

"Neden sağduyulu davranıyoruz? vatan bizim namus bizim! nasıl getirdiyseniz öyle geri götürün".

"O küçük tartışmanın illa da kanlı kavgaya dönüşmesi mi lazım ki mültecileri ya kamplara ya da Suriye'de güvenli bölgeye göndereceksiniz”?

"Suriyeliler toplatılsin kamplarda yasasinlar".

"Bunlar daha başlangıç... Siz bir de Suriyeliler biraz daha palazlansın o zaman görün. Hepsini kamplara toplayıp oradan da geldikleri yere göndermek şart”.

"Ne 3 milyonu adım başı her yerdeler her şehirde her kasabada saylları en az 7-8 milyon en azzz en azzz"

"Bu kadar insanı yem serper gibi tüm Türkiye saçarsanı demografik yapıyı bozarsinız ve böyle kavga dövüşler boy gösterir bunu bilmek için Prof olmaya oxford bitirmeye gerek yok"

"Yardımcı olmak ise maksat; sinıra kamp kurarsın orada barındırı yardım edersin. Kontrol altında tutarsin. Bizde nasıl"....

"Bunların örf ve adetleri bize hiç uymuyor sanki uzayl gibiler ve çok rahatsız edici hareketleri var. Bir an önce bunlar bir alanda toplanmall yoksa gidişat iyi gözükmüyor" $r$.

Bir diğer yorum çeşidinde ise göçmenlerin ülkelerini terk etmeleri ciddi bir eleştiri konusu olmakta hatta bazı okuyucularda göçmenlerin ülkelerinde kalıp savaşmalarını öğütleyen bir söylem geliştirmektedir. Bunlardan bazıları;

Bizim tepkimiz Suriyeli yaşlılara kadınlara çocuklara değil genç erkeklere neden ülkenizde savaşmadınız ülkemizde savaşs olsa biz başka ülkeye kaçmaz savaşırız

Gitsinler ülkelerini korumak için savaşsınlar. Huzur kalmadı

Suriyeli gençlerin yeri burası değil, gidip ülkelerini kurtarsınlar, onları istemiyoruz. Hele ki beleşten üniversitede okudukların da duyduk ya... Gidin.

"Bizim gençlerimiz 20 yaşında askere gidip şehit oluyorlar. 3 aylık acemi birliğinde mi savaşçı oluyorlar yani. 6-7 yıldır Suriye'de savaş var, burada zevki sefa etmeseler savaşmayı ögrenmiş olurlardı"

"Burada saldırgan tutum gösterip kavga çıkaracak kadar "cesur" olanlar, ülkesinde savaşacak kadar savaşçıdırlar".

"Çanakkale' de 14-15 yaşında Türk evladı savaş eğitimi mi almıştı da kaçmadılar? Vatanı için savaşmanın gereği, savaş eğitimi almak değildir, vatan sevgisidir. Hepsi defolsun gitsin, beleş yaşamasinlar".

"Suriyeli gelsin sahilde nargile içsin benim askerim orada savaşsin. Bu nasıl bir anlayış ki eli silah tutabilecek bu insanlar toplanıp gidip kendi ülkelerini kurtarmaz? Siz kurtarın".

"Her Türk erkeğine 20 yaşına gelince askerlik yapma mecburiyeti varda bunlara da olsun eğitimi verin gönderin bizim askerimizin yanına Suriye'ye savaşsınlar".

Çalışma boyunca sık sık ifade edeceğimiz üzere bu yorumlar genel bir bakış açısını yansıtmıyor olsa bile gelinen noktada geçici koruma altındaki Suriyeli göçmenlere ilişkin 
politikalar artık misafirlik söylemi üzerinden değerlendirilemeyecek kadar karmaşık bir yapı arz etmektedir. Bugün Türkiye nüfusunun neredeyse \%5'ine karş1lk gelen Suriyeli göçmen sayısının yıllar içerisinde sürekli artış göstermesi ve yerel halkın kentlerde göçmenlerle aynı kamusal alanları paylaşmaları, beraberinde büyük sorunlar doğurmaktadır. Ev sahibi konumundakilerle göçmen konumundakilerin farklı gerekçelerden ötürü sıkça karşı karşıya geliyor olması ötekileyici tutumu daha da güçlendirmektedir.

\subsection{Ekonomik Kaygılar Üzerinden Yapılan Yorumlar}

$\mathrm{Bu}$ tema altında Suriyeli göçmenlerin işgücüne katılım sürecine dair bir kısım yorumlarda ne şekilde değerlendirildikleri irdelenmektedir. $\mathrm{Bu}$ manada göze çarpan en önemli rahatsızlık ise devlet kaynaklarının Suriyeli göçmenlere aktarılması noktasında yoğunlaşmaktadır.

Erdoğan'ın (2014:30) araştırmasında halkın \% 70,7'sinin, Türk ekonomisinin göçmenlerden dolayı zarar gördüğü görüşündedir. Bununla beraber, \% 61,2’i Türkiye'de yoksullar varken Suriyelilere yardımların yapılmasına da ciddi itiraz getirmektedir. Ayrıca ORSAM'ın (2015) Şanlıurfa, Kilis, Hatay ve Gaziantep'te yaptığı "Suriyeli Mültecilerin Türkiye'ye Ekonomik Etkileri: Sentetik Bir Modelleme" adlı çalışma raporunda ise, bu illerde işini kaybeden kişiler $\% 40$ ile $\% 100$ arasında değişen oranlarda işlerini kaybetme nedeni olarak Suriyelileri görmektedir. Suriyelilerin var olan iş firsatlarını ellerinden aldıkları ve ücretlerin azalmasına neden olduklarına dair inanç, Suriyelilere karşı bir tepki açığa çıkmaktadır. Benzer diğer çalışmalarda da açığa çıkan temel sonuç ise; Suriyeli göçmenlerin işgücü piyasasına ve devlet kaynakları üzerinde yarattığı etkilerdir. Bu bakış açısının ana akım haber sitelerindeki yorumlara yansıma biçimi ise genel olarak şu şekildedir:

"Misafir" dediğin 3-5 gün olur. 5-6 yıldır misafir bunlar ve hazır "yiyor"! Ne zamana kadar besleyeceğiz bunları? Devlet bunlara tanıdı̆̆ hakları kendi vatandaşına tanımiyor". olmaz”.

"Devlet Suriyelileri devlet kurumlarına memur olarak atasın!!!. bu tür slkntılar

"Bu Suriyeliler yüzünden yolunu şaşırıp Türkiye'ye gelen turistler de büyük rahatsizlık duyuyor. Son derece rahatsız bir durum".

"Suriyeliler klytırıktan tapu alıyorlar vatandaş oluyorlar bizim ülke vatandaşlarına doğru dürüst hizmet vermiyor hey gidi heeey"

"Yan gelip yatarak devletin parasiyla beslenmek ne güzel...Ben Türk olarak yan gelip yatmak istesem bile vergi ödüyorum işim yok diye”.. çekmektedir.

"Benim vergimle Suriyelileri besliyorsunuz"... şeklinde yorumlar dikkati

$\mathrm{Bu}$ yorumlardan da anlaşılacağı üzere Suriyeli göçmenlere ilişkin ortaya çıkan ekonomik kaygılar, devlet kaynaklarının kullandırılması noktasında yoğunlaşmaktadır. Göçmenler çoğu zaman ekonomik sıkıntıların asıl kaynağı olarak görülebilmektedir.

Ayrıca yapılan araştırmalarda Suriyelilerin işgücü piyasasına etkileri de bu kaygıların artmasına neden olan bir diğer faktördür. Herhangi bir sebepten dolayı iş yerinden 
çıkan-çıkarılan kişiler, -buna sebep göçmenler olmazsa dahi- bir şekilde göçmenleri durumla ilintilendirerek onları "günah keçisi" haline getirebilmektedirler.

\subsection{Uyum/Kardeşlik Üzerinden Yapılan Yorumlar}

Suriyeli göçmenlere dair olumsuz yorumların çokluğuna karşın olumlu yorumlar oldukça azdır. Olumlu yorumların genellikle "Ensar - Muhacir" anlayışı yani İslami bir söylem üzerinden yürüdüğü, geri kalan yorumların ise toplumsal kaygılar üzerinden şekillendiği görülmektedir. Bu yorumlardan bazıları şu şekildedir:

“Ensar olun”...

"Bir suç varsa da başka bir suçla sorun çözülmez. Amaç sokakları terörize etmek"

"Bazı provokatörler Suriyeli kardeşlerimizi kötü göstermeye çalışıyor”.

"Vatandaşlık verilse topluma çabuk entegre olurlar. Okul iş günlük hayat olur".

"Hani onlar muhacir biz Ensar'dlk yakıştı mi size mutaassip kardeşlerim...evlerinizi açmanız gerekirken yaptıklarınıza bakın bir...Suriyelilere geçmiş olsun".

"Irkçıllk yapmayın. Biraz insaflı olun. Türk olan suç işlemiyor mu hemen Suriyeli suç işleyince tepesine çöküyorsunuz. Irkçılık şeytandandır hepimiz bir Allah'ın kuluyuz..... gibi ifadeler yer almaktadır".

Nihai olarak; haber başlıkları ve içeriklerindeki olumsuz çağrışımlar bir arada değerlendirildiğinde bu çalışmada olumlu yorumların az sayıda olması doğal görülebilir.

\section{Sonuç}

Dünya'nın en vahşi vekâlet savaşlarından birine dönüşen ve zaman geçtikçe içinden çıkılamaz bir hâl alan "Suriye savaşı", Türkiye açısından da Suriyelilerin geçicilikten kalıcılığa doğru evrildiği bir noktaya taşınmaktadır.

Başlangıçta Türk hükümet yetkililerinin, Suriye rejiminin halkın taleplerine karşı daha fazla dayanamayacağı düşüncesi, Suriye'nin “Arap Baharı”nın son durağı olacağ beklentisi ve küresel aktörlerin Suriye krizine bu denli müdahil olabileceğinin öngörülememesinin de etkisiyle Türkiye, Suriyeliler için sığınılacak en öncelikli ülke halini almıştır. Suriye için bir türlü "gel(e)meyen bahar", Türkiye için zorlu bir sürecin doğurmuştur. Gelinen bu noktada Türkiye, göçlerden kaynaklı yükün büyük bir kısmını çeken ülke konumundadır.

Göçmenlerin başlangıçtan bu yana misafir olarak anılması ile bugün uzayan bu sürecin artık bu kavramlar üzerinden açıklanamayacağı ve sosyal gerçekliği açıklamada yetersiz kaldığı bir gerçektir. Bu sürecin uzaması toplumsal mutabakatı derinden etkileme riskini de büyütmektedir.

Türkiye'nin kapsamlı bir mülteci politikasının halen netleşememesi, yabancı düşmanlığı/nefret, ayrımcı, dışlayıcı, ötekileştirici söylemlerin (basmakalıp sözler) artma riskini doğurmaktadır. Suriyeli göçmenlerin Türk medyasında temsil ediliş biçimleri "doğru bilinen yanlışlar" gibi görsellerin sıklıkla tekrarı, göçmenlerin ötekileştirilmesi sürecine katkı sağlamakta, toplumsal uyumu olumsuz yönde etkilenmektedir. $\mathrm{Bu}$ sıkıntıların aşılmasında medya temsilcilerinin hassasiyetleri önem arz etmektedir. 
İşgücü piyasasında yaşanan sıkıntıların ve algının ötekileştirici tutumu beslediği görülmektedir. Suriyelilerin işgücü piyasasına katılımı da, katıl(a)mayıp dilenmeleri de ötekileştirici tutumu körükleyebilmektedir. Göçmenlerin ekonomiye yük olmayıp aksine katkı sağlayarak yeni bir güç olabilmesinin önü açılmalıdır. Aksi durumda ise göçmenlerin ülke ekonomisi üzerinde daha da ağır bir yük olmasının kapısı aralanmış olacaktır. $\mathrm{Bu}$ gerçeklikten hareketle kalıcılığa doğru evrilen bu süreçte başta Türk vatandaşlarının hassasiyetlerinin gözetildiği, birlikte yaşama dair ekonomik politikalar ortaya konması gerekmektedir. Göç Yönetiminde aktör pozisyonunda olanların misafirlik durumuna dair kapsayıcı politikalar ortaya koyması, ülkede göçmenlere karşı başlangıçtan bu yana büyük oranda olumlu yönde gelişen bakış açısının sürdürülebilirliğine katkı sağlayacaktır.

Son olarak değinmek gerekirse, münferit bazı olaylar üzerinden tüm göçmenlerin problemli olduğu, bütün suçların kaynağı olduğu ve yerli halkın neredeyse tamamının bu kişilere karşı bir nefret ya da aşağılama söylemini benimsediği gibi bir algı yaratma çabası, Türkiye'nin başlangıçtan bu yana gösterdiği insani hassasiyetleri görmezlikten gelmek olacaktır. Aradan geçen 7 yıla rağmen ciddi bir çatışma zemininin oluşmamasından da anlaşılacağı üzere, Suriyeli göçmenlerle alakalı haberler üzerinden yürütülen bu tartışmaların halkın ortak düşüncelerini yansıtmaktan uzak olduğu söylenebilir. Ancak süreç uzadıkça göçmenlerin toplumsal konumunun "ötekilik" tecrübesi üzerinden şekillenmeye başladığı da göz ardı edilmemesi gereken bir gerçektir.

\section{Kaynakça}

Akkayan, T. (1979). Göç ve Değişme, İstanbul Ünv. Edebiyat Fak. Yay., İstanbul.

Altunışık R. vd. (2012) Sosyal Bilimlerde Araştırma Yöntemleri, Sakarya Yayıncıllk, 7. Bask1, Sakarya.

Çağlar İ ve Özkır Y. (2015) Suriyeli Mültecilerin Türkiye Basınında Temsili, Açılım Kitap, İstanbul.

Erdoğan, M.M.,(2014). Türkiye'deki Suriyeliler: Toplumsal Kabul ve Uyum Araştırması. Hacettepe Üniversitesi Göç ve Siyaset Araştırmaları Merkezi, Ankara

Fıchter, J. H. (2012). Sosyoloji Nedir, Çev.: N. Çelebi, Anı Yayınları, Ankara.

GİGM (2017) İdare Faaliyet Raporu 2016, T.C. İçişleri Bakanlığı Göç İdaresi Genel Müdürlüğü Yayınları

Göç Vakfi. (2018). http://gocvakfi.org/turkiye-siginmacilara-ev-sahipliginde-dunyadabirinci-sirada/ (Erişim tarihi: 24.09.2018)

Göker ,G. ve Keskin ,S. (2015) Haber Medyası ve Mülteciler: Suriyeli Mültecilerin Türk Yazılı Basınındaki Temsili, İletişim Kuram ve Araştırma Dergisi - Sayı 41 / Güz, Gazi Üniversitesi İletişim Fakültesi Süreli Elektronik Dergi

http://iletisimdergisi.gazi.edu.tr/site/index.php/IKAD/article/view/204 (Erişim tarihi: 03.09.2018)

Guibernau, M. (1997) "Milliyetçilik: 20. Yüzyılda Ulusal Devlet ve Milliyetçilik", Çev.: N.N. Domaniç, Sarmal yay., İstanbul.

HaberTürk Gazetesi, İnternet arşivinde yer alan 'Suriyeliler' başlıklı tüm haberleri, 2017 (Ocak-Ekim)

Hürriyet Gazetesi, İnternet arşivinde yer alan 'Suriyeliler' başlıklı tüm haberleri, 2017 (Ocak-Ekim)

Kümbetoğlu, B. (2012) "Sosyolojide ve Antropolojide Niteliksel Yöntem ve Araştırma", Bağlam yayınları, 3. Basım, İstanbul.

Parsons, T. (1964) "The Social System”, Collier Macmillian: Toronto. 
Onur, H. F. (2003) "Öteki Sorunsalının" Alterite" Kavramı Çerçevesinde Yeniden Okunması Üzerine Bir Deneme" H.Ü. İ.İ.B.F dergisi, Cilt:21 Sayı:2, ss.:255-277,

http://dergipark.gov.tr/huniibf/issue/7881/103567 (Erişim tarihi: 23.02.2019)

ORSAM (2015) "Suriyeli Mültecilerin Türkiye'ye Ekonomik Etkileri: Sentetik Bir Modelleme" $\quad$ Rapor No: 196, http://www.orsam.org.tr/eski/tr/trUploads/Yazilar/Dosyalar/201519_rapor196tur.pdf (Erişim tarihi: 25.08.2017)

Özbek, T. (2006) "Nusayri Etnik Kimliğinin Simgesel Oluşumu”, Mustafa Kemal Üniversitesi Sosyal Bilimler Enstitüsü, Yayımlanmamış Yüksek Lisans Tezi.

Sabah Gazetesi, İnternet arşivinde yer alan 'Suriyeliler' başlıklı tüm haberleri, 2017 (Ocak-Ekim)

Schnapper, D. (2005) Sosyoloji Düşüncesinin Özünde Öteki ile İlişki, Bilgi Üniversitesi Yayınlar1, İstanbul.

Sirkeci İ. ve Cohen J. H. (2015) Hareketlilik, Göç, Güvensizlik, İdeal Kent Araştırmaları Dergisi, Say1: 15. Ankara.

UNHCR (2017) Global Trends forced displacement in 2017, http://www.unhcr.org/5b27be547.pdf (Erişim tarihi:.11.09.2018)

Türk, E. (2016) "Postmodernite Ve Kültürel Farklılıkların Tanınması Bağlamında Çokkültürlülük Tartışmaları", Uluslararası Sosyal Araştırmalar Dergisi, Cilt: 9 Sayı:42, ss.1155-1163

Türk, E. (2016) "Hızlı Kentleşme Sürecinin Toplumsal Yapıya Etkileri: Batman Örneği” Sakarya Üniversitesi Sosyal Bilimler Enstitüsü, Danışman: Prof. Dr. Mustafa Kemal ŞAN, Yayınlanmamış Doktora Tezi.

Yıldız, S. (2007) "Kimlik ve Kimlik Kavramının Toplumsal Niteliği”, Milli Folklor, sayı:74 ss.9-16, http://www.millifolklor.com/PdfViewer.aspx?Sayi=74\&Sayfa=6 (Erişim tarihi: 23.02.2019) 